\title{
Religious individualisation and collective bhakti: Sarala Dasa and Bhima Bhoi
}

'The author remains a mettlesome subject in late modernism', writes Christian Novetzke, 'confounding a simple definition of what it is to be an author' (Novetzke 2003, 214). ${ }^{1}$ Novetzke skilfully unravels the distinct layers of authorship that went into the conferral of 'authority' on one particular figure, Namdev, in traditions 'not born of modernity yet fully present in the modern world'. In doing so, he argues against the modern notion of the author as a solitary, creative figure. In this chapter, I seek to extend his insights about 'corporate authorship' to an examination of the interface and mutual imbrication of individuality, individualisation, and institutionalisation of authors and texts in Odisha, eastern India in 'medieval' and 'modern' times.

The confounding and conflation of the individual and the collective, and the medieval and the modern, also underlies bhakti (devotion). Bhakti or the spirit of bhakti, widely accepted as the hallmark of medieval India, particularly the north, is simultaneously personal and communitarian. Often represented as a female being and usually translated as devotion, bhakti is 'heart religion'; it emanates from divine encounter of individuals with the divine, an encounter that engulfs them with love, passion and joy, and inspires them to break out in poems and songs. Their exhilaration infects others with effervescent enthusiasm, resulting in a 'glorious disease of the collective heart' (Hawley 2015, 2). Bhakti's effervescence makes the individual and the collective, and autonomy and heteronomy, mingle in intriguing ways. Bhakti is intensely personal but hinges on sharing and communion. It is also liberating - from societal hierarchies, sectarian rivalries, and Sanskritic supremacy.

How then should we classify bhakti? As medieval or as modern? Is it medieval because the sensibility is entirely religious, inflected by the miraculous? Or is it modern because it is individual, autonomous, and emancipatory? What is the sense of the 'individual' and the 'person' we assume when we call bhakti individual and personal? Does bhakti encompass and supersede the modern? Or do we need to find different ways to think about the ancient, the medieval, the early modern, and the modern? Is it possible to think of the inextricable blends

1 My sincere thanks to Anne Feldhaus for referring me to this essay. And also to all the other members of our discussion group - Rahul Parson, Ian Henderson, Max Deeg and Saurabh Dube - for suggestive observations. 
in which the individual and the collective, the personal and the social, the author and the reader merge and mutually constitute each other? And if we do, how would we think of individualisation and institutionalisation? These questions will become pertinent as I address, and try to gain entry to, the world of a 15th century sudra (lowercaste/varna) Odia poet who composed a vernacular Mahabharata upon the command/blessing of the goddess Sarala. ${ }^{2}$

Needless to say, the miraculous is not unique to India or bhakti or the medieval. It is current in several other traditions, starting from the ancient Greek. Homer, I was reminded during my talk at the Max Weber Kolleg in June 2017, was traditionally said to be blind and his compositions the result of a miracle. Even though scholars have tried to discard such beliefs as legends or fables, the debates on when, how, and under what circumstances the Iliad and the Odyssey were composed, and whether one or several authors composed them, are far from settled.

Bhima Bhoi, a mid-19th century poet-philosopher of Mahima Dharma, a radical religious faith of Odisha, is also believed to have been born blind and bestowed with the 'eyesight' of knowledge by his preceptor Mahima Swami, the founder of the Dharma. Mahima Swami in turn, is taken to be an incarnation of the Absolute whose mahima (radiance/glory) he preached. Although the authorship of Bhima Bhoi's compositions has not been questioned by scholars, the fact of his blindness has been interrogated. In addition, texts composed decades after his death have been ascribed to him, a fact that testifies to Bhima Bhoi's appeal to the popular imagination, as well as to the enduring legacy of his 'authorial agency in a way similar to the tradition of Namdev' (Novetzke 2003, 215). In my earlier work, I have explored the notion of corporate authorship by paying attention to the process of composition and transmission of texts and have argued in favour of shared composition through collective reading and recitation. My purpose has been to interrogate the binaries of orality and writing, literacy and illiteracy, and text and performance, in order to raise important issues with regard to the author and authorial voice (Banerjee-Dube 2003, 1-17; 2007).

In this essay, I will examine the Mahabharata in Odia ascribed to Sarala Dasa, an adi or early poet of vernacular Odia, and will briefly touch upon Bhima Bhoi's own compositions and those other texts that have been attributed to him in order to trace the constitution and mobility of texts and authors in the very process of their actualisation in interpretive reading. This will, perhaps, enable a different understanding of institutionalisation and individualisation. I will draw upon and extend Michel de Certeau's suggestive idea of reading as 'poaching', an interpretive exercise that questions 'the assimilation of reading to passivity' and

2 Odia is used now both to refer to the people of Odisha (earlier Orissa) and the language they speak. 
asserts that 'every reading modifies the object' - the text - (De Certeau 1984, 169). At the same time, I will not follow de Certeau's formulation of the written text and the reader as two separate and well-defined entities. I will further track the implications of Roger Chartier's arguments about how written texts get their meanings through the forms in which they are received, understood, and appropriated by readers/listeners, resulting in their 'actualization' by means of 'concrete practices and interpretive procedures' (Chartier 1992, 50). By asserting that in medieval Europe and in later times, written texts were routinely recited in collective gatherings of readers/listeners who were not 'literate', and that such collective reading conferred differential meanings on the texts on account of the diverse expectations of readers, Chartier forcefully brings home the 'instability' of meaning in apparently fixed, written texts (see Chartier 1992; 1989, for instance).

Such insights acquire a distinct significance in India, where reading and recitation have had an equal, if not greater, importance and texts have been composed (and actualised) through their performance and circulation. With this in mind, we will look into the elaboration of Sarala Dasa's rendering of the epic in the vernacular as the Mahabharata in Odisha and of Sarala Dasa as the adi kabi (early poet) of Odia. This supreme importance of the Mahabharata moreover, can be attributed to the fact that it is an imaginative re-telling, or 'reconceptualization', rather than a translation of the 'original' version (Satpathi, Nayak forthcoming; Patnaik 2012, viii).

\section{Sarala's Dasa?}

Sarala Dasa, like so many other (ancient and) medieval saints, bhaktas, and composers, comes to us through a series of mediations. First, his Mahabharata, composed in the 15th century, spread and circulated through recitations and collective readings and that were copied and re-copied on palm-leaf manuscripts (believed to have an average life of 35-40 years) for over three centuries before it was printed in the late 19th century. The first 'definitive' version of the Odia epic, collected, compiled, and edited by Artaballav Mohanty and his large team of scholars, was published by the Department of Culture of the Government of Odisha in 1966. Until the late 19th century, innumerable copies of palm-leaf manuscripts of the Sarala Mahabharata could be found in ordinary and royal households as well as in the village bhagabata ghara (a shed/hut where the Odia Bhagabata and other devotional texts were read out). It is redundant to point out that the 'original' Mahabharata also underwent a similar process of circulation before being written down. 
The legends about Sarala Dasa's life comprise the second mediation. Arguably, such legends are an offshoot of his great composition. At the same time, the inextricable blend of a goddess, her will, command, and blessing, with the poet's devotion to her make it difficult to state with certainty whether the legends spread after the composition, or the legends and the composition together went into the making of Sarala Dasa, the servant/servitor of goddess Sarala as the composer of the Odia Mahabharata. We can turn to two such legends, taken from an early scholarly exposition on Sarala Dasa, to sample a taste of the genre.

An ordinary peasant is ploughing his field. In order to get rid of tiredness and boredom and to energise himself and his bullocks, he starts singing chautishas, short verses of 34 letters, taken to be the earliest literary expression in vernacular Odia. But fatigue overcomes him and he keeps forgetting the words. A little forlorn, he starts praying to istadev (personal god). A woman figure appears and demands to know why he has stopped singing. She says that she greatly enjoys hearing him sing and commands him to compose the Mahabharata in Odia. After the figure disappears, an amazed and bewildered peasant, Sarala Dasa, starts singing again, successfully this time. These chautishas do not exist any longer. But the Mahabharata, composed through the icchhashakti, the force of will, wish, or desire of the woman/goddess, has endured, together with three other compositions by the same peasant.

Consider a second scenario. While Sarala Dasa is ploughing his field one day, messengers from the royal palace come in search of a suitable match for the king's daughter. They talk to Sarala Dasa, are thoroughly impressed by his intelligence, and take him to the palace as a possible partner for the princess. A simple, unlettered peasant, Sarala Dasa is alarmed and overwhelmed when the princess comes to him with her offerings on a plate to welcome him as her life partner. Awe-struck, he hides under a cot. Irked, the princess expresses disdain for a stupid, ignorant farmer, throws away the plate and offerings, and leaves the place. Chastised and humiliated, Sarala Dasa decides to dedicate himself to the acquisition of knowledge. He reaches the temple of Sarala Devi (goddess Sarala), only to find her missing. He closes the temple door and sits in meditation. The goddess is pleased and commands him to compose the Mahabharata in order to please her. A perplexed Sarala Dasa responds in despair that it was impossible for him to undertake such a difficult task. The goddess asks him not to panic and instructs him to pick up the quill from the road the next day and go sit under the Kalpabat (wish fulfilling tree). The scenes of the Mahabharata will, she tells him, become visible to him there. All he needs to do is write them down.

It is significant that the Mahabharata, or the version in print at least, mentions a lekhana, something to write with. The typical image of bhakti poetry 
involves spontaneity, with the blessed one, touched and engulfed by the divine, instinctively breaking out into songs that affect and overwhelm other hearts to create a storm or a wave that makes selves move and flow into one another. At other places in the text, the poet recounts how he only needed to recite the Mahabharata the Devi was to speak in his ears.

Through legends and stories, Sarala Dasa, the son and servant of the goddess Sarala, appears at once as a symbolic subject and an embodied person who probably does not carry the meanings and significance attached to the concept of the modern individual as a bounded intentional subject. And yet there are nuances and ambiguities that we need to address. Who is Sarala Dasa? A person who consciously calls himself the servant (dasa) and putra (son) of the goddess Sarala, or a symbolic name ascribed to the 'author' of a composition that is constituted in the very act of its corporate recitation, reading, and narration? In other words, what I am trying to get at are not the real facts about a person who assumes 'Sarala Dasa' as a title to emphasise the miraculous powers bestowed on him by the goddess but, rather, the possibility of a constitutive instability of the author and his text(s).

Scholars have not, it might be argued, yet questioned the existence of Sarala Dasa as a person. On the contrary, his compositions have been combed through to find historical facts about his life, his place of residence, and of happenings in Odra rashtra or Odra desha, as current Odisha, with its different and changing frontiers, was referred to at the time (Panigrahi 1976). Indeed, there was a debate in the 1950s between a well-known historian and an acclaimed writer over the location of Sarala Dasa's village and the time of the composition of the Mahabharata, with each claiming to have meticulously studied the details provided by the poet himself and the language used in his composition to come to very different conclusions (Panigrahi 1956; Mohanty 1956). Subsequent authors have sustained or questioned the arguments advanced by either the historian or the writer without probing whether such a Sarala Dasa existed.

This ready acceptance of Sarala Dasa as the author of the Odia Mahabharata has been due to the inscription of an authorial voice in the text. At the beginning or end of each canto, Sarala Dasa comes in as the narrator: 'so says Sarala Dasa kabi' or 'Sudra muni' Sarala Dasa. The question is whether, given the several mediations I have indicated above, we can simply assume the existence of Sarala Dasa on the basis of these pronouncements or whether we need to consider the possibility of an unstable author and a collective authorship through which a 'narrational self' is constructed in the transmission and circulation of the text? If we follow this latter course, how should we understand the individual, the self, the collective, the personal, the social, and their interface? 


\section{Sarala's Mahabharata}

In the edition compiled by Mohanty that I have consulted, Sarala Dasa begins with an invocation of Sarala Devi (goddess Sarala), the mangalacharan, and then moves on to describe in detail the location of the village in which the great goddess Saralachandi resides. This is followed by a declaration of the identity of the author/composer. Significantly, Sarala Dasa calls himself Sarala Dasa kabi (poet Sarala Dasa), the son of Saralachandi, upon whose command he is composing the Mahabharata. There is an interesting twist here. Goddess Sarala, a manifestation of goddess Chandi, sometimes linked to the tantric devi Bimala who is still the adhisthatrti devi (presiding deity) of the Jagannath temple in Puri, is addressed as pankajbasini and parama-vaishnavi in the Mahabharata. Pankajbasini means one who dwells on the lotus and the term is normally associated with Lakshmi, the spouse of Vishnu and goddess of bounty and wellbeing. Supreme vaishnavi, in turn, might represent Lakshmi or a supreme worshipper of Vishnu. Some, however, have identified the goddess Sarala with Saraswati, the goddess of learning who also had links to tantra. We will not be able to parse this intriguing mix-up here. Suffice it to say that there are clear indications of a degree of turmoil within the divine hierarchy, beginning in the 13th century, with Shiva and Shakti being gradually displaced by the rise and increasing prominence of Vishnu worship and the conferral of the status of state deity to Jagannath by the Ganga kings, a theme I have examined elsewhere and which Heinrich von Stietencron discussed decades ago.

Let us return to the Mahabharata. Immediately after the invocation of the goddess and the declaration that Sarala Dasa is composing the Mahabharata to carry out the devi's command, the poet implores wise men not to find faults with his work. He is ignorant from birth and is not a pandit, a learned man. Again, in the second chapter of adi parva (the first book), he declares that he is sudra by jati (caste/calling) and ignorant, that he lives by the manual work of cultivation along with his three brothers. He has had no 'education' but is a great devotee of Sarala Devi, who he hopes will forgive him for embarking upon this daring venture. A few couplets later, Sarala Dasa mentions his journey to the abode of Govinda (Vishnu), where he came into the company of saints and wise men and gained knowledge. He also refers to himself as 'sudra muni', a sudra saint or a saint among the sudras, probably to emphasise the knowledge he acquired through Sarala devi's blessings and by coming into contact with saints and wise men.

Hence, even if we accept the person/individual Sarala Dasa as the author, his words tell us that his self is simultaneously individual (personal) and collective, and that his prodigious composition is the result of a collectivised self, a self that is constituted both by an unlearned person who is moved by the command/wish/ blessing of a goddess and by the knowledge acquired from wise and learned men. 
On the other hand, according to Jatin Nayak, a retired professor of English literature at Utkal University currently engaged in translating the Sarala Mahabharata into English, the Sarala Mahabharata is a very 'self-reflexive' text. 'The Mangalacharana and invocation in his Mahabharata', he comments, 'leave the reader in no doubt as to the ambivalence of the author and the text, even when he was defending the enterprise by taking recourse to divine intervention and inspiration' (Satpathi, Nayak forthcoming).

Is Sarala Dasa consciously taking 'recourse' to divine intervention as a 'trope' or is he moved by the 'divine command' which is, for him, intuitively real? We cannot be certain. From his own statements and their subsequent readings it appears that Sarala Dasa's individual selfhood, marked by low-birth and ignorance, is elevated through its intimate relationship with the divine. There seems to be an assertive affirmation, upheld by the use of the first-person-singular in the text: Sarala Dasa, an ignorant sudra is blessed with the power to compose an exceptionally elaborate and unique text. A text that is mediated by his own vision/hearing/apprehension of the Mahabharata narrative and is constituted, in turn, through continual actualisation and interpretation in collective readings poised on a common stock of knowledge and the expectations of communities of readers/listeners (Chartier 1989, for instance). The enmeshment of hearing, seeing, and composing and/or writing is found in the text itself: while at one place the poet states that he was to sit under the Kalpabat with a quill to write the Mahabharata, at others he alludes to seeing the scenes of the epic or hearing it through the voice of Sarala Devi.

The Odia Mahabharata can, therefore, be seen both as a collective composition of the goddess and her command/blessing, the poet, and the knowledge acquired from wise and learned men on the one hand, and, on the other, as a composite construct of the 'author' and the readers/listeners. Its authorship is inspired by the wish-command-vision-blessing of the divine, articulated through the vision-hearing-imagination of the poet, and moulded by the perceptions and aspirations of the readers.

Let us dwell a little longer on the singularity of the Odia Mahabharata. Apart from a facile correspondence with the Sanskrit epic in the number of parvas (books), 18 to be precise, and in the main protagonists, the Odia version differs in the sequence and extension of the parvas, in the storyline, and in the portrayal of the main characters. It introduces new events and characters, including a significant story about the indestructability of Krishna and his transformation into Nilamadhaba and later Vishnu/Jagannatha, the central deity of Hinduism in Odisha. It also leaves out very important episodes, such as the Vishawarup darshan, i.e. the Bhagavat Gita part of the Sanskrit epic. Indeed, a recent scholar has argued that Sarala's story is 'purer', since it excises 'deliberations of a philosophical 
nature' and proffers a picture of Krishna's intervention in human affairs based on a different understanding of the nature of divine intervention (Patnaik 2012, viii). An intertwined relation between the human and the divine, and an absence of 'philosophical deliberations', accounts for a 'pure' version of an epic that is closer to the heart of the simple folk of Odisha. Sarala Dasa, we need to remember, calls his text the Mahabharata, leaving it unclear whether he is composing a new one or rendering a vernacular version of the Sanskrit epic. This contrasts with Tulsidas's Ramacaritmanas, for instance, an extremely popular 16th century vernacular rendering of the Ramayana, where the reference to an original is continually present. ${ }^{3}$

To cite Jatin Nayak again, an 'illusion of sameness and an illusion of difference are being created at the same time' (Satpathi, Nayak forthcoming). The poet follows certain textual strategies to conserve the idea of the Sanskrit Mahabharata but never refers to it directly. And even though the main protagonists remain, their names are rendered in colloquial, 'rustic' Odia - Yujhesthi for Judhisthir and Mahodar (one with a huge belly) for Bhima - with their depictions differing widely from those in the Sanskrit version of the story. Sakuni, the violent villain, is given a very empathetic portrayal, even when his violence is emphasised and exaggerated. The Pandavas, by contrast, receive a somewhat dismissive treatment. Gandhari and Kunti are made 'hilariously realistic' through the 'natural and petty jealousies which are inseparable from feminine nature', and (river/mother) Ganga is portrayed as 'an impetuous, imperious and tyrannical shrew'. Draupadi, the forceful heroine of the Sanskrit epic, is made to 'sigh deeply over her fate' when she is married to five brothers (Mansinha 1962, 52-7).

Significantly, the entire drama of the epic, it is stated recurrently by my colleagues and acquaintances in Odisha, is set in the milieu and topography of what was then Odra desha or Odra rashtra (current Odisha), a fact that made the text intimate and accessible. Moreover, its claim to be a 'history' from creation onwards, with realistic references to contemporary place names, rivers, and mountains, brought it even closer to the hearts of its readers/listeners, as they could easily identify and relate to the text.

It is perhaps in order here to invoke Roger Chartier's argument once again and pose the question of whether this 'materiality' of the text, the concrete topographic references, for instance, were inherent in the text or whether they resulted from the intervention and interpretation of readers who con-

3 I draw upon Luis Gamaliel Quiñones Martínez's unpublished MA dissertation, 'Vernacularización e identidad en el reino de Varanasi', CEAA, El Colegio de México 2017. 
stantly participated in the composition and evolution of the text. Readers, Chartier affirms, 'never confront abstract, idealized texts detached from any materiality' (Chartier 1992, 50); the form of the text governs the modalities through which it is read or heard and that modality produces meaning. In other words, in a scenario in which the Mahabharata is being recited or performed by one or many, the content of the text is shaped by the dispositions of the community of readers: their active perception, expectation, and interpretation. In such a context, it is eminently possible that the names of places and personalities, as well as the events of the Mahabharata, were moulded by the dispositions and perceptions of the readers/audience. Instead of the readers easily identifying with a text that is accessible on account of its concrete references, the text may have taken shape and been transformed through traditions of reading and the expectations of interactive readers and audiences. This accounts for the numerous versions Artaballav Mohanty and his team of scholars collected, compared, selected from, and edited, beginning yet another process of 'corporate composition', albeit one that we will not be able to discuss in detail here.

All accounts indicate that Sarala's Mahabharata found an immediate and overwhelmingly popular response. In a world of collective reading and performance, and at a time when vernaculars as languages of literary expression were becoming increasingly important, characters, figures, episodes, and narrations of the Odia Mahabharata acquired real and symbolic significance. Certain phrases became metaphoric and almost axiomatic, while certain characters became representative of real lives and figures. Even today, these phrases and characters are common knowledge in Odisha, as I have been told repeatedly by my friends and colleagues in Bhubaneswar. Hence, for people with very little knowledge of the Sanskrit text, Sarala's Mahabharata could and did become the Mahabharata.

What would be the 'original' or the 'putative' original in this context and for whom? And how do we understand the relation between the putative original and its vernacular rendering? Sarala Dasa's Mahabharata, it has been emphasised by the several scholars and students I have spoken to in Bhubaneswar, is not a 'translation'; it is a re-telling of the Sanskrit narrative with its own anecdotes, emphases, and interpretations, which are sufficiently extensive that they come together to form a new telling. It is a telling, re- or new, in which the events of the Mahabharata are concurrent with important events of Odra desha and in which they occur in regions and places within Odisha. Is it history? What kind of history is it? Imaginative, intuitive, or interpretive? Can it be called history at all? Leaving readers to ponder these issues, I turn to the later, modern apprehensions of Sarala Dasa and his compositions. 


\section{Kabi and canonisation}

'The emergence of Sarala Dasa in the mid-15th century was phenomenal. The track-record of Oriya literature before him was not such that it could have thrown up a writer as substantial as he was [...] His is the first case where an individual talent not only changes a tradition, but sets up a new one for subsequent generations to follow' (Mohanty 2006, xxi).

In this recent History of Oriya Literature, Sarala Dasa is not only an individual but also an exceptional one: a genius who breaks with an earlier tradition and starts a new one. And yet the break with an earlier tradition and the beginning of a new one does not constitute a 'modern' rupture, since the tradition begun by Sarala Dasa is suffused with bhakti, devotion, and pertains to both the 'ancient and the medieval'. According to Mohanty, modern Odia literature began roughly in the mid-19th century and supplemented the spirit of devotion and love with that of nationalism and a concern with the 'human predicament' in a hostile world. Clearly, there is an understanding of the 'modern' here as being rooted in the 'human', as distinct from the religious and the divine, and in the real conditions of the social world. But it accords to Sarala Dasa the status of an extraordinary individual in the modern sense of the term.

It is worth stressing that it was precisely in the second half of the 19th century, i.e. with the beginning of the 'modern' period in Odia literature, that Sarala Dasa and his compositions drew increased scholarly attention and his status as adi kabi, the early poet of vernacular Odia, acquired greater significance. The renewed interest in the language and culture of Odisha was tied both to the growth of incipient nationalism against colonial rule and to a fight for the survival of Odia against the encroachment of Bangla (Bengali) in the coastal districts. This struggle inspired a new sense of pride in Odianess and instilled with urgency the search for a genealogy of Odia that precedes, and is distinct from, Bangla. Towards the end of the century, this struggle was taken up with greater vigour by Odia speakers of the western region against the encroachment of Hindi. This sustained bhasha andolan (language movement) eventually led to the creation of current Odisha as a unified, separate province of Odia speakers in 1934 (Banerjee-Dube 2015, Chap. 5 for a brief overview).

The search for a linear history of Odia language and literature was stimulated further by an important project launched by the University of Calcutta in the first decades of the 20th century, aiming to compile histories of vernacular literature. This, together with the need to uphold and emphasise the uniqueness of Odia against more dominant languages, resulted in the 'discovery' and retrieval of the early poets of the language who were credited with laying the foundation of the 'national literature of Orissa' (Mazumdar 1921: xiv).

Interestingly, this process of compiling a linear history of vernacular Odia was fraught with ambivalence and ambiguity, reflected in the diverse assessments of 
Sarala Dasa and his Mahabharata over the late 19th and early 20th century. Even while the pronounced hesitation of the late 19th century in openly acclaiming the achievement of a 'rustic' poet narrating an epic becomes less in the early 20th, it does not disappear completely. If there is pride in the fact that the Odia Mahabharata was composed prior to many other vernacular renderings, there is also discomfort, not just with its wide variations and deviations from the 'original' story but also with its uncultured, even 'vulgar', language, its incorporation of many folk tales, and its lack of metrical sophistication. Sarala Dasa's categorisation as adi poet often comes very close to the characterisation of his works as aadim (primitive) or ancient, in a slightly pejorative sense of the term.

Both Mrutyunjaya Ratha's 'Saralacharit', published in 1911 and subsequently included in his collected works published in 1971, and B. C. Mazumdar's Typical Selections from Oriya Literature volume 1, published in 1921, assert that the variation in the number of letters in the 14-letter metre of dandibruta can be accounted for by the fact that the text was meant for recitation. What appears to be an imperfection was corrected when the Mahabharata was read aloud. Ratha adds that this dandibruta of the Mahabharata sounded more like prose than poetry and was easier for non-literate people to understand (Ratha 1971, 197). His forceful affirmation that Sarala Dasa was born in the early 15th century and was the adi kabi of Odia, goes hand in hand with the statement that this Mahabharata is aadim, primitive, and contains all the features of primitive literature: an ungrammatical language full of prakrut words, descriptions expressive of superstition, un-truth and the vulgarity of rural, rustic folk (ibid., 198).

Early appraisals of Sarala Dasa emphasise his low birth and his lack of formal education and knowledge in order to explain his simplicity and rustic style and metre. These features also serve to establish a distance between the world of the cultured, 'modern' subject and that of a rustic medieval peasant who nevertheless composed an epic that caught the popular imagination for centuries. A simultaneous acceptance and distancing is carried out in the double move of valorising Sarala Dasa as the adi kabi and placing him squarely among the simple, the rural, the unlettered folk of Odisha, diffusing thereby his significant influence in the configuration of Odia cultural identity.

Indeed, the numerous 'deviations' in the Sarala Mahabharata, and the several liberties he took in retelling the story, prompted Fakirmohan Senapati, regarded as the father of Odia prose literature - and now also called 'Vyasakabi' a kabi who like Vyasa, produced the Mahabharata - to translate the original Sanskrit Mahabharata into Odia. He took eight years, from 1898 to 1905, to translate 4 of the 18 parvas. This partial Odia translation, however, did not gain the favourable reception that Fakirmohan was hoping for, even among the cultured circle of the Odia literati of Bhubaneswar and the coastal region. In his autobiography he 
mentions how the Sarala Mahabharata and other devotional texts still continued to be read out in important households (Senapati 1977).

The spread of print culture and the printing of the Odia Mahabharata went hand in hand with attempts to standardise and homogenise the several versions of Sarala's Mahabharata and to edit its uncomfortable anecdotes. Some printed versions even sought to correct the 'irregularities' in the famous dandibruta.

Such attempts to bring the Sarala Mahabharata into line with elite expectations of what the epic should be gradually changed over the 20th century as Sarala Dasa's low birth and status came to acquire prominence and began to be touted as a sign of Odia 'genius'. The period of his emergence and the flowering of Odia literature became tied to the founding by Kapilendra Deva of a local Hindu Odia dynasty, the Suryavamsa (the solar dynasty). It is interesting that Kapilendra is recorded as an usurper in historical accounts while also being praised for his patronage of the local language. There is no direct indication of any court patronage of Sarala Dasa by Kapilendra, a point that goes against Sheldon Pollock's observation that the 'break with the Sanskrit tradition' and the flowering of vernaculars as languages of literary practice happened under the patronage of local courts and rulers (Pollock 2006). However, Kapilendra and the short-lived solar dynasty are still coupled with the adi kabis of Odia in scholarly representations of a time during which Odia literature attained its 'highest glory' (Mazumdar 1921: xviii).

Sarala Dasa's gradual elevation in status is reflected in the History of Oriya Literature, written by the poet and scholar Mayadhar Mansinha:

'Sarala Dasa, the poet of the Oriya Mahabharata, flourished in the reign of the founder and the greatest ruler of the Solar dynasty, Sri Kapilendra Deva [...]. This commoner-king carried the Oriya arms down to the banks of the Kaveri down to Warrangal and beyond, into the very heart of the South Indian Moslem powers of those days. [...] Sarala Dasa was born in such political conditions and such propitious times. True national poet that he is, we find all these happy contemporary conditions, clearly reflected in the vigorous narrative of his great Mahabharata' (Mansinha 1962, 51).

Another important history of Oriya literature, written in Odia and first published in 1963, placed Sarala Dasa's compositions confidently in the adi parva (first stage) of Odia literature, which began with the Buddhist caryapadas. This History, however, did not show any unease with the lack of sophistication in Sarala Dasa's compositions. The compositions of Sarala Dasa are, according to this work, replete with the 'cultural characteristics' of this first stage, in which sagas of heroes predominated, sagas that underscored bravery and courage as well as sacrifice and spirituality, rather than the desire and pleasure that would mark out the second stage of Odia literature (Mohanty 1977, pp. 1-2). 
By the 1960s therefore, Sarala Dasa had been both individualised and institutionalised: two processes that complemented and sustained each other. At the same time, Mansinha's essay also bears witness to the uncertainty that besets an intellectual in his attempt to valorise a poet and a composition that lack 'sophistication'. At one point in the essay, Mansinha admits that despite many 'unique and excellent qualities', Sarala Dasa's epic, 'owing to his lack of any formal education and systematic training and comprehensive erudition', has the appearance of 'a wild growth' (Mansinha 1962, 64). We are tempted to compare this with Mrutyunjaya Ratha's description of the Mahabharata as 'primitive literature'. The Sarala Mahabharata, Mansinha hastens to add, is popular with the people for the very reasons that make it a 'wild growth'.

Such reservations notwithstanding, an increasing association with religious devotion, simplicity, and earthiness as the hallmarks of Odia language and literature that articulate the voice of the people of the soil, has substituted ambivalence with pride in the poor, unlettered poets as true representatives of the 'genius' of Odisha. With linear histories of Odia literature establishing Sarala Dasa as both an adi kabi and a 'national poet', the instability of both Sarala Dasa as an individual author and also his collective and itinerant compositions have become institutionalised through a new set of mediations and appropriations. The collection and compilation of the several palm-leaf manuscripts of the Mahabharata that accepted Sarala Dasa as the individual author, the attempts to edit and standardise the language and metre, and the careful selection of the 'correct' version from among numerous variations of the Odia epic, have simultaneously established Sarala Dasa as an individual and also institutionalised him as the sole author of the Mahabharata.

It is time now to look at another rural poet of late 19th century Odisha who belongs to a radical faith before tying together the strands of poets and their compositions, individual and collective authorship, and individualisation and institutionalisation.

\section{Bhima Bhoi and bhakti}

Bhima Bhoi, the poet-philosopher of Mahima Dharma, a radical religious faith preached in the 1860s in Odisha by an itinerant ascetic named Mahima Swami, was initiated into Mahima Dharma by the preceptor. The Swami also endowed the blind, poor Khond (adivasi) Bhima Bhoi with the 'eyesight of knowledge' and the gift of poetry to spread the message of the faith. Like Sarala Dasa, Bhima Bhoi grew up with no formal education. However, prior to Mahima Swami's bestowal of 
knowledge and the gift of poetry, Bhima Bhoi is believed to have heard and assimilated the message of popular devotional texts and epics collectively read out in village gatherings. He combined such knowledge with the precepts of Mahima Swami to elaborate a philosophy/theosophy of Mahima Dharma. His rich compositions reflect the varied trends of religious thought current in Odisha and underscore Bhima Bhoi's ingenuity in imbuing prevalent ideas with new meanings.

Bhima Bhoi emerged as a preacher after his Guru's death, then took up the life of a householder, severing ties with the ascetics of the faith, and set up his own ashram in Khaliapali in western Odisha in the last decades of the19th century, where he slowly replaced the Guru as the founder of the faith. His colourful life and rich compositions generated a host of legends while his emotive chants of devotion and spoken/written compositions produced a surfeit of meanings at collective readings/ recitations in gatherings of non-literate followers. In western Odisha, Bhima Bhoi merged with and/or displaced Mahima Swami as the founder of Mahima Dharma.

At a different level, Bhima Bhoi's invocation of the evil Kali Yuga, the last and worst of the four classical yugas (epochs) in Hindu time reckoning, and his appeal to all to take shelter in the true preceptor without further delay, took on a particular resonance amongst his followers at times of crisis in their lives and within the faith. The collective compositions that conferred great credibility and significance on Bhima Bhoi also meant that apocryphal texts were ascribed to him after his death.

The deification of the poet by lay disciples was complemented by a process of canonisation begun by intellectuals in the early twentieth century. Once again, the ambivalence about an unlettered poet of low birth, which characterised the late nineteenth-century reports of officials of the princely and colonial states, changed into admiration at the turn of the century. An essay on 'Bhima Bhoi's acquisition of knowledge' appeared in the literary magazine Mukur in 1908; this was soon followed by two influential texts of N. N. Vasu, a scholar-official Modern Buddhism and its Followers in Orissa (1911) and The Archeological Survey of Mayurbhanja (1912). In these texts, Vasu categorically identified Bhima Bhoi as the leader of the sect and paid him glowing tributes:

'Ere long the fame of Bhima Bhoi spread far and wide. Hearing his immortal instruction helping in the attainment of real knowledge and illumining the head and the heart, the mighty pillars of the caste system stooped at his feet, though the blood of the low kanda ran in his veins. They considered him a spark from the Eternal Flame of truth and knowledge. Before several years had elapsed the Mahima Dharma could count its followers by thousands' (Vasu 1911, 164).

Vasu's adulation of Bhima Bhoi's low birth, which was seen to only heighten his achievements, was felt by others as well. B. C. Mazumdar, an official of the 
Sonepur court and the editor of Typical Selections, credited Bhima Bhoi with 'a charming and commanding personality' that enabled him to lead an attack on the temple of Jagannatha in Puri in 1881 (Mazumdar 1911, 126). Colonial records confirm that Bhima Bhoi did not lead the attack. At the same time, it is highly probable that Bhima Bhoi's compositions, which mentioned that Lord Jagannatha had left Puri to become Mahima Swami's first disciple, inspired the group of very ordinary men and women who marched to Puri from western Odisha to take out and burn the lifeless image of Lord Jagannatha (Banerjee-Dube 2007, 110).

Mayadhar Mansinha, whom we have cited above, also wrote in glowing terms about Bhima Bhoi, who called himself a 'kandha' (khond) in his compositions. Bhima Bhoi was described as 'the greatest adivasi poet' and a 'revolutionary', a symbol of the genius of adivasi (aborigine) Odisha. (Mansinha 1976, 206). In histories of Odia literature written in the vernacular, Bhima Bhoi was raised to the status of a 'national poet', alongside Sarala Dasa and other early poets, and given the credit for occasioning an awakening of the Odia people (Misra 1928, 278). Interestingly, the fact that Bhima Bhoi used 'impure' words in his compositions, 'words used very commonly by the illiterate', was commended as proof of his experiments with language and literature and upheld as poetry close to the heart of the common people.

In other words, simplicity, lack of formal education, earthiness, and the rustic style of the early poets, as well as that of Bhima Bhoi, came to be increasingly valorised as 'devotional poetry' underwent the process of being constructed as the hallmark of Odia literature, a true expression of the voice of the people. Unsurprisingly, therefore, Sarala Das' sudra status, his spirited personality, the striking changes he made to the 'original', the new episodes he introduced, and the deviant interpretations of the epic he provided, have been seized upon as the conscious innovations of a creative genius that resulted in a break with an earlier tradition and the creation of a new one. An early poet with a 'medieval' sensibility inaugurates the 'early modern' in Odia literature by reconceptualising a Sanskrit epic through devotion and the blessing of a goddess and by providing a lower caste interpretation of a 'Brahminical' text.

Bhima Bhoi, for his part, is hailed simultaneously as a social revolutionary and an outstanding composer whose works bear a close resemblance to those of the early poets (and medieval mystics) in terms of language, thought, and content. He is a late 19th century devotional poet who pertains to the medieval in the thrust of his compositions. He is also modern because he caused a social revolution by speaking out against the caste system and boldly using 'impure' words in his creations.

Bhima Bhoi's commanding personality, radicalism, and affinity with the medieval mystics that caught the imagination of his followers, found expression 
in the circulation of malikas, apocryphal texts ascribed to him in the early decades of the twentieth century. Such malikas rolled Gandhi and Mahima Swami together into the figure of Kalki, the tenth incarnation of Vishnu, whose appearance was to bring the evil Kali Yuga to an end and re-establish satya dharma (true faith). The avatar, human incarnation of the divine, proclaimed by such texts had appeared once - in the figure of Mahima Swami. But the devotees had failed to recognise him. He was to appear again and this time the true devotees were not to falter. They were to take shelter at his feet and also fight along with him against the evil forces of Kali Yuga (represented by the British among others) to wipe away evil and clear the path for a bright future. Bhima Bhoi's distress at the evils of Kali Yuga and his call to all to take refuge in the Absolute to cope with these evils became pertinent in the disturbed times of colonial rule and during the grassroots surge in nationalist agitation under the leadership of Gandhi in 1920-21. Bhima Bhoi's emotive bhajans, which acquired new meaning and content in the collective singing of devotees during his lifetime, became a source of solace at a later stage through the creation and circulation of texts ascribed to him. If in the process of canonisation by the literati and of diverse apprehensions by the adherents of Mahima Dharma, Bhima Bhoi became individualised and institutionalised, the inherent fluidity of his compositions enabled the production of new ones in his name, reinforcing the mobility and lack of fixity of Bhima Bhoi and his compositions.

\section{By way of a conclusion}

In order to sum up a very preliminary foray into this subject matter, let me raise a few questions that do not have ready answers. How do we gain access to a text and its composer? How do we understand both through the multi-layered mediations and mutations they have undergone? What do Sarala Dasa and Bhima Bhoi, and their texts, tell us? That both authorship and texts/compositions are corporate and collective? That even if texts are taken to be the creation of an individual author, they speak different languages, are understood in diverse ways and acquire lives of their own? In such a scenario, it is perhaps fruitful to track the journey(s) of the text and the author to gain a better understanding of texts without closure and of authors who are simultaneously individual and composite. Such a reading could make the author a less 'mettlesome subject' and enable us to reflect on authorship and subjectivity in new ways.

Sarala Dasa and Bhima Bhoi, as well as their compositions, offer instances of collective authorship and of personal and communal selves. While Sarala Dasa's relationship with Sarala Devi and that of Bhima Bhoi with his preceptor is acutely 
intimate, both exemplify social and composite selves that enmesh the divine, the human, and the community of readers and listeners in distinct ways. Such entwined articulations account for the mobility of their compositions, as they were circulated and reconstructed in a process of evolutions that spanned centuries. If this mobility made the Odia Mahabharata's relation with the putative Sanskrit 'original' almost negligible and conferred on Sarala Dasa an authority of great proportions, Bhima Bhoi's authorship and authority was reinforced in the composition of newer texts that were ascribed to him after his death. In both cases, the authors, corporate to start with, became individualised and institutionalised through the work of a collective.

The mutual imbrication of a subjective self and a social subject, and fused practices of creation and reading, author and audience, enable us to move beyond modern understandings of the author as a creative individual and his creation the 'text' - as two separate well-defined entities. Further, it allows entry into a world in which the author and audience, reading and composition, get rolled together into one, displacing the well-defined boundaries of the self and the individual, the personal and the collective. It is time to start looking afresh at notions of the individual and individualisation, keeping in mind these fascinating combinations of the ancient and the medieval, and the early-modern and the modern, the religious and the rational, and the individual and its 'other'. Keeping these in view, we can begin to rethink the notion of institutionalisation.

\section{References}

Banerjee-Dube, I. 2003. 'Reading time: texts and pasts in eastern India', Studies in History, 19:1. 1-17. An abridged version reproduced in Historical Anthropology. Oxford in India Readings in Sociology and Social Anthropology, ed. S. Dube, New Delhi: Oxford University Press, 2007. 149-64.

Banerjee-Dube, I. 2007. Religion, Law, and Power: Tales of time in eastern India, 1860-2000. London: Anthem Press.

Banerjee-Dube, I. 2015. A History of Modern India. Cambridge/Delhi/New York: Cambridge University Press.

Chartier, R. 1989. 'Leisure and sociability: reading aloud in early-modern Europe.' In Urban Life in the Renaissance, eds. S. Zimmermann, R. S. E. Weissman, Newark: University of Delaware Press \& London, Associated Press. 103-20.

Chartier, R. 1992. 'Laborers and voyagers: from the text to the reader', Diacritics 29, 2. 49-61.

de Certeau, Michel. 1984. The Practice of Everday Life. Trans. Steven F. Rendall. Berkeley: University of California Press.

Hawley, J. S. 2015. A Storm of Songs: India and The Idea of Bhakti Movement. Cambridge MA: Harvard University Press.

Mansinha, M. 1962. History of Oriya Literature. New Delhi: Sahitya Akademi. 
Mazumdar, B.C. 1921. Typical Selections from Oriya Literature, vol.1. Calcutta: University of Calcutta (published by the Baptist Mission Press).

Misra, B. 1928. Oriya Sahityara Itihasa. Cuttack: Utkal Sahitya Press.

Mohanty, G. 1956. 'Sudramuni Sarola Dasanka abirbhaba samaya', Jhankara 8, 4. 388-401.

Mohanty, J. N. 2006. History of Oriya Literature. Bhubaneswar: Vidya.

Novetzke, C. L. 2003. 'Divining an author: the idea of authorship in an Indian religious tradition', History of Religions 42, 3. 213-42.

Panigrahi, K. C. 1956. 'Sarala Dasanka ghara keunthi?', Jhankara 8, 5. 457-71.

Panigrahi, K. C. 1976. Sarala Sahityara Oitihasika Chitra (Historical Depictions in Sarala Literature). Bhubaneswar: Prajatantra Prachar Samiti.

Patnaik, B. N. 2012. Introducing Saaralaa Mahaabhaarata. Manasagangotri, Mysore: Central Institute of Indian Languages.

Pollock, S. 2006. The Language of the Gods in the World of Men: Sanskrit, culture, and power in premodern India. Berkeley/Los Angeles/London: University of California Press.

Ratha, M. 1971 (1911). 'Sarala Charita', reproduced in Mrityunjaya Granthabali, vol. 1, Cuttack: Students Store, 1971. 200-01.

Satpathi, Sumanyu; Nayak, Jatindra K. unpublished. 'Introduction', to the English translation of Sarala Mahabharata.

Senapati, F. 1977. Atmacarita. Trans. Maitree Shukla. New Delhi: Sahitya Akademi.

Vasu, N. N. 1911. The Modern Buddhism and its Followers in Orissa. Calcutta: U. N. Bhattacharya.

Vasu, N. N. 1912. Archeological Survey of Mayurbhanja. Calcutta: U. N. Bhattacharya. 